\title{
Current Issues of Reorganization Process in the Czech Republic
}

\author{
Monika Randáková, Jiří Strouhal, Jiřina Bokšová, Luboš Smrčka, and Raluca Simona PL Bonaci
}

\begin{abstract}
The aim of the research is to determine how many companies in the Czech Republic which have been permitted to reorganize submitted a proposal to allow the reorganization before bankruptcy decision and also how many companies have been permitted to reorganize simultaneously with the bankruptcy decision. The particular goal was also to determine how many companies that have been allowed reorganization had approved reorganization plan to begin the recovery business process. Within the application part of this paper authors focus on specific case of reorganization in lottery company Sazka.
\end{abstract}

Index Terms - Reorganization, reorganization plan, secured creditors, Czech Republic, Sazka.

\section{INTRODUCTION TO LEGAL TREATMENT OF INSOLVENCY IN THE CZECH REPUBLIC}

Since as early as the eighteenth, and especially the second half of the nineteenth century, the Czech economic environment was among the more important industrial areas in Europe. Within the territory of the Austro-Hungarian Empire, the Czech lands were certainly the most developed region in this regard. The first legal code concerned with bankruptcy was the Bankruptcy Regulations from 1781 (the "Josephine"); this was replaced by a new bankruptcy act in 1868, which remained valid until 1914. The legislative amendment at the time outlasted not only the war, but also the genesis of the Czechoslovakian Republic and was changed by the Bankruptcy, Compensation and Opponent Code in 1931. As we can see, the pressure rapidly grew for accelerating the creation of new legislations; the regulation accepted during the reign of Emperor Joseph II remained in effect for almost ninety years; its successor lasted 46 years, and was replaced after seventeen years, after which the whole process was interrupted by the Second World War. In 1951, the act from 1931 was abolished by the acceptance of the Civil Court Regulation and was not replaced in any way - the socialist economic system did not need any mechanisms in its planning system for solving business bankruptcies: Outside of a few minor exceptions, neither production nor providing of services were conditioned by market pressure, but were intended to behave within the diction of the plan as far as possible. The concept of bankruptcy lost its meaning.

Following the revolution in 1989 and the rapid transformation of Czech economy from a centrally-planned

Manuscript received March 25, 2013; revised June 1, 2013.

Monika Randáková, Jiří Strouhal, and Jiřina Bokšová are with the Department of Financial and Managerial Accounting, Mladá Boleslav, Škoda Auto University, Czech Republic (e-mail: randakova@is.savs.cz; ystrouhal@is.savs.cz; boksova@is.savs.cz). to a market economy, it was necessary to return to bankruptcy law and renew its operation within the context of nascent market relations. Act No. 328/1991 Coll. on Bankruptcy and Compensation was accepted. In order to understand certain habits and fears prevailing in the Czech economic environment and in the second decade of the $21 \mathrm{st}$ Century, it is necessary to understand the atmosphere in which this act was accepted. At the given time there were still only a minimum of privatized businesses. The formerly "national businesses" were gradually transformed into "joint-stock companies" or "limited liability companies"; privatization progressed at a dynamic pace, but in many cases it was uncontrolled (using loopholes in the legislation at the time), and sometimes even contrary to valid laws. Nevertheless, economic subjects in the country were unusually strongly interconnected and heavily dependent on one another owing to the traditional delivery of components. There were many "monopoly" manufacturers, whereas foreign competition was disqualified in many fields thanks to the Crown exchange rate. On the other hand, domestic producers specializing in export lost their usual markets within a short time (the USSR and other Socialist Bloc states), they had to reorient themselves towards new markets unusually quickly. Besides this, there was also a particular state of judicature - the vast majority of judges had cooperated with the previous regime, but it was primarily the judges who neither know nor comprehended market relationships and the market system, its relations and logic. This fact was well known among the professional public and fears grew as to how judicature would be able to cope with the application of something as unknown to it as bankruptcy law. In reality, this whole system had ceased to function practically since the Communist revolution in 1948, as numerous business were nationalized practically overnight, whereas large businesses were under state ownership from as early as 1945 and 1947. More than forty years had thus elapsed before the reinstatement of bankruptcy law, and if we were to include the period of the Second World War, we could speak of an entire half-century of disrupted continuity. The act from 1991 was abolished by the coming into effect of a new regulation, 182/2006 Coll. On Bankruptcy and Approaches to its Solution (called the Insolvency Act in practice) - although this act was accepted in 2006, fears of its impact were so strong that its coming into effect was postponed until 1 January 2008. The Act on Bankruptcy and Compensation had thus served for almost eighteen years - and it was criticized as being poor and hardly usable for the same amount of time.

Reorganization is a new way of dealing with bankruptcy of companies, which is implemented in Czech legal system. According to US Bankruptcy Law (chapter 11 of USBC) is the main purpose of reorganization creditors' satisfaction 
from revenues of debtors' continued operations in case there wouldn't be done a cash settlement of company's assets [1]. It usually involves restructuring of liabilities and capital accounts together with revaluation of the company assets.

Under the term of reorganization it is understood the gradual satisfaction of creditors' claims while preserving the debtor's business. The approved reorganization plan is an action, following which should lead to restoring of the company [2].

"The advantage of the reorganization is mainly the fact, that involved parties can get more than they would receive in bankruptcy. On the other side the main disadvantage is likely, and experience from abroad confirms so, that the process is very long, complicated, and costly based primarily on resolving conflicts between the interests of creditors and owners [3]."

"In the approval negotiations of the reorganization and subsequently in the process of preparation of the reorganization plan should be taken primarily into consideration the going concern basis in the future - after reorganization plan is fulfilled. Afterwards should be assessed the financial situation in terms of generation of available funds to pay down debts according to the reorganization plan and ultimately should be taken into account the structure of meets just one from the above mentioned two conditions. The Insolvency Act allows the reorganization also to the debtors, who submit the reorganization plan approved at least by half of all secured creditors and half of all unsecured creditors or approved by at least $90 \%$ of the creditors present at the meeting of creditors (always calculated by the amount of their claims). Under these conditions the turnover or the number of employees are not take into account. "Only the practice will show whether setting of the gates into the reorganization according to the Insolvency Act is in principle correct, too hard or too soft. [4]".

"Since the target of the reorganization is the maintenance of business activity of the enterprise, it is important to realize that the reorganization itself applies only to the enterprise (entrepreneur) [5]".

"This is very important especially in case when the reorganization is carried out of a debtor who is a physical entity entrepreneur. In this case, could be applied this kind of solution only to the property in ownership of the entrepreneur, which is used to run a business [6]."

At present most authors deals with insolvency proceedings from a legal perspective [7]-[9]. Accounting perspective is currently greatly neglected by the professional community [10]. Among other authors, who are at least partially accounting or tax view of the reorganization and insolvency proceedings all involved.

As is the case in similar legislative amendments in developed countries, the Czech Insolvency Act too is a legislation which prevents the possibility of creditors individually enforcing receivables in the event of a debtor's bankruptcy, replacing such individual rights with regulations for collective enforcement. In the Czech Environment, it thus applies that property seizure or other acts of individual enforcement are automatically halted as soon as an insolvency proposal is filed (or more precisely, after a decree is issued reporting the beginning of insolvency proceedings) in the Insolvency Register (\$109, Para. 4 InsA). The insolvency proceeding must be commenced only on the basis of a proposal - in the case of a debtor, submitting a proposal for himself is in fact sometimes obligatory; if the company's proprietor or management does not fulfil this obligation, they risk both financial and disciplinary recourse (e.g. injunction on activity). In certain cases, executives could in fact be investigated on suspicion of committing a criminal offence. Currently it applies that debtors whose insolvency is either evident (inability to pay) or hidden (over-indebtedness) are obliged to file a proposal.

A proposal can be filed either by creditors or debtors; where a proposal on the grounds of impending bankruptcy is concerned, only the debtor is obliged. In the area of legal entities, the favoured methods for settling bankruptcy are declarations of bankruptcy and reorganisation. The first case primarily involves the liquidation method, whereas the second case involves the financial rehabilitation method; this means that, in the first case, it is not assumed that the insolvency proceeding will result in the preservation of a debtor's business in a form even remotely similar to its state before bankruptcy. On the contrary, where reorganisation applies, it is assumed that the main aim of insolvency proceedings is to preserve the debtor's business as a whole, as an economic unit with its employment and other attributes.

However, in view of certain circumstances there are cases where a declaration of bankruptcy leads to the preservation of manufacture in the debtor's company, and also to preservation of employment (the debtor's assets are sold as a business to an interested party. Similarly, the opposite also applies - reorganisation carries a certain advantage in terms of time for the creditor. This is because from the legal point of view, declaration of bankruptcy is intended to facilitate the monetisation of the debtor's assets, which is not necessarily an ideal solution for creditors. Especially in times of reduced asset value, some creditors may find it more advantageous to bide their time and offer the assets on the market at a later stage. This variant, however, is not made possible by declaration of bankruptcy, or the implementation of such a procedure is not without problems in a bankruptcy. Nevertheless, reorganisation plans are relatively loosely defined in the Insolvency Act $(\$ 338-363$ InsA) and it is easy to conceive of a version where its fundament is the financial preservation of assets and their sale within a certain timeframe which also need not necessarily be literally defined.

The Insolvency Act distinguishes two forms of bankruptcy - insolvency and over-indebtedness. Insolvency (inability to pay) is defined as a state in which the debtor is unable to fulfil his monetary liabilities for a period longer than thirty days after their due date. The fulfilling of non-monetary liabilities cannot be enforced by means of bankruptcy law, but only individually. Over indebtedness is directly defined as a state when "the sum of his (the debtor's) liabilities exceed the value of his property" ( $\$ 3$, Para. 3 InsA). In both cases (insolvency and over-indebtedness) it is possible to observe a requirement which is normal in the legal statutes of developed countries, i.e. the requirement of a multitude of creditors (more than one creditor). Procedural subjects are the insolvency court, the debtor, creditors claiming 
receivables on the debtor's part, the insolvency administrator (perhaps other administrators if the insolvency administrator summons one to aid him), the state council (in cases where it enters insolvency proceedings or participates in an incidental lawsuit for some reason) and finally, the debtor's liquidator could also be a procedural subject. The debtor and creditors with reported and recognised receivables are the participants in proceedings. The insolvency administrator is not a participant in the proceedings, but has an independent position to both the bankrupt debtor and the creditors - he cannot be considered to be the representative of the creditors - the creditors' representative in this sense of the word is the creditors' meeting or creditors' commission to the extent that these are empowered by law and also to the extent that they are empowered by the creditors during the meeting.

The Insolvency Act distinguishes between a preliminary administrator and an insolvency administrator. The preliminary administrator is appointed by the court for the period between the filing of the proposal and the bankruptcy ruling, in cases where he deems this appropriate. While the judge should be designated for a case on the basis of an allocation of work according to previously set regulations the principle of time is usually recognised - the preliminary administrator is selected by the court (the president of the insolvency court) from a list of insolvency administrators. An insolvency administrator is appointed by the court when ruling on bankruptcy at the latest. If a bankruptcy ruling does not solve the matter, it is assumed that the preliminary administrator will perform this duty.

Creditors have the right to relieve this administrator and then to appoint their own administrator, also selected from the list of insolvency administrators. In the Czech economic environment it is said that this possibility exists practically at any time, but this is not the case. The Act specifically states (\$29 InsA): “At the earliest creditors' meeting which takes place after the review hearing, the creditors may resolve to relieve the insolvency court-appointed administrator from his duties and appoint a new insolvency administrator. This resolution is accepted if it is approved by vote by at least half of all creditors registered on the day preceding the holding of the creditors' meeting, counted according to the amount of their receivables." This creditor decision is confirmed by the court, but it is practically only a formal confirmation. However, if the creditors do not agree to relieve the original administrator within this time frame, their ability to do so afterwards becomes considerably more complicated ( $\$ 31$ InsA). This provision is in fact conceived for cases where the administrator falls ill or is unable to further perform his duties; in reality, however, it is possible to utilize it even if lawsuits between the creditors or creditors' commission and the administrator occur.

The court may appoint a representative for the insolvency administrator in a case where the administrator is unable to perform his duties for a fixed period. This representative can be relieved by the creditors in a similar manner to the insolvency administrator. Furthermore, the law recognises the institute of a separate insolvency administrator whom the court appoints in cases where the insolvency administrator is disqualified from certain legal acts owing to his relationship to certain creditors. If the administrator is disqualified from certain duties because they conflict with the joint interests of the creditors in insolvency proceedings in which the insolvency administrator has also been appointed, the court will always appoint a separate administrator for these purposes ( $\$ 34$ InsA). Finally, the Insolvency Act also recognises the institute of a special insolvency administrator for cases where an especially complex problem in proceedings requires expert specialisation.

Registration in the list of insolvency administrators requires taking appropriate examinations, proof of prescribed education, integrity and fulfilment of other conditions.

Creditors file their claims; the administrator and the remaining creditors can, however, deny these and their validity is then adjudicated by a lawsuit. In recent Czech practice, almost all lawsuits concerned with a given insolvency proceeding are heard at the same court, which is motivated by the desire to accelerate the progress of the proceedings. Creditors are divided into groups according to the extent of their claims on the yields taken from liquidating the debtor's assets ( $\$ 57$ InsA). According to $\S 49$ InsA, it applies that, unless otherwise stated by the law, the creditors' meeting is decided by a simple majority of present votes regardless of creditor groups. In the majority of important cases, it is decreed that secured and non secured creditors are to vote separately. This applies also in such cases where shareholders and partners are considered a group of creditors. The creditors' commission should not be comprised of a majority of secured creditors. Clause $\S 57$ of Ins A state that the number of members of the creditors' committee proposed by secured creditors cannot be higher than the number proposed by non-secured creditors. The negotiations of the creditors' committee can also be attended by the debtor's employees (through a labour union); they have an advisory role in such cases.

\section{Problem Formulation AND RESUltS}

The aim of the research was to determine how many companies in the Czech Republic which have been permitted to reorganize submitted a proposal to allow the reorganization before bankruptcy decision and also how many companies have been permitted to reorganize simultaneously with the bankruptcy decision. The particular goal was also to determine how many companies that have been allowed reorganization had approved reorganization plan to begin the recovery business process. For the statistical research were selected only those companies which have been permitted to resolve the bankruptcy by reorganization. This represents 33 approved reorganizations in the period from 1. 1. 2008 till 31. 3. 2012.

Statistical survey has helped to discover quite surprising and unexpected results. 24 companies from 33 have submitted a proposal to allow the reorganization before bankruptcy decision. It is almost $73 \%$ of them. On the contrary, insolvency court allowed reorganization only to 5 companies from these 24 at the same time as bankruptcy decision. This is proof that it is an important decision requiring detailed analysis of all possible alternative solutions to revive company and enable the creditors profit 
more than in bankruptcy solution.

We tried to test a hypothesis that "For $80 \%$ of the companies that allowed the plan may be submitted simultaneously with the proposal for reorganization, the time will not permit the reorganization and authorization of the reorganization or within 120 days after the approval of the reorganization plan longer than one year." According to research done this hypothesis was fully approved. 33 companies were still allowed reorganization, of which only 18 companies were previously approved reorganization plan. Time from approval to permit the reorganization of the reorganization plan was not longer than one year in 16 companies, which is more than $88 \%$.

We did also found out that out of 18 analyzed companies, 16 companies have at least one secured creditor. As the result of research: only 3 companies of those, which are undergoing reorganization in Czech Republic, do not have banking house in place of secured creditor. This means, that $88 \%$ of companies (14 out of 16), which got approval for their reorganization plan and have secured creditor, are actually controlled during reorganization process trough banking houses such as Komerční banka (Societe General Group); Česká spořitelna (Erste Group); Raiffeisenbank; ČSOB (KBC Group); or UniCredit Bank (see Table I).

\begin{tabular}{|c|c|c|c|c|c|}
\hline \multirow[t]{2}{*}{ Company } & \multirow{2}{*}{$\begin{array}{c}\text { Commencement } \\
\text { of insolvency }\end{array}$} & \multirow{2}{*}{$\begin{array}{l}\text { Approval of } \\
\text { reorg. plan }\end{array}$} & \multirow[t]{2}{*}{ Duration } & \multicolumn{2}{|c|}{ Secured creditors } \\
\hline & & & & banks & others \\
\hline CEREPA & 22.8 .2008 & 15.10 .2009 & 419 & 1 & 0 \\
\hline SCHOELLER Litvínov & 23.12 .2008 & 4. 12.2009 & 346 & 2 & 0 \\
\hline Elitex slévárna & 27.1 .2009 & 19.2 .2010 & 388 & 1 & 0 \\
\hline FEREX - ŽSO & 16. 4. 2009 & 27.4 .2010 & 376 & 2 & 3 \\
\hline KORDSERVICE SK & 4.5 .2009 & 11.5 .2010 & 372 & 1 & 0 \\
\hline KORDÁRNA & 4.5 .2009 & 21.4 .2010 & 352 & 1 & 0 \\
\hline SLOVKORD & 4.5 .2009 & 16. 11.2010 & 561 & 1 & 0 \\
\hline DAGRO Plzeň & 24.3 .2009 & 5.5 .2010 & 407 & 1 & 0 \\
\hline Teplická strojírna & 26.10 .2009 & 31.5 .2011 & 582 & 1 & 1 \\
\hline Javořice & 17.2 .2010 & 31.10 .2011 & 621 & 0 & 3 \\
\hline FREEZART PLUS & 21.5 .2010 & 26.4 .2011 & 340 & 2 & 3 \\
\hline NERIA & 6.8 .2010 & 16.1 .2012 & 528 & 1 & 3 \\
\hline ČKD Kutná Hora & 5. 10.2010 & 21.2. 2012 & 504 & 0 & 5 \\
\hline Přerovská dopravní společnost & 7. 10.2010 & 16.9. 2011 & 344 & 0 & 0 \\
\hline $\begin{array}{l}\text { Starorolský porcelán } \\
\text { Zdekauer }\end{array}$ & 19.1 .2011 & 7.12 .2011 & 322 & 0 & 3 \\
\hline BEDZETI & 10.2. 2011 & 16. 4. 2012 & 431 & 0 & 0 \\
\hline STROJÍRNY DOSPIVA & 7.3.2011 & 3.6 .2011 & 88 & 3 & 0 \\
\hline MANEX \& Co & 26.5 .2011 & 7.2.2012 & 257 & 1 & 0 \\
\hline \multicolumn{3}{|c|}{ Average duration of the process } & 402 & & \\
\hline
\end{tabular}

The reorganization plan constitutes very extensive and detailed document according which the process of reorganization is going to run in the practice. Its main aim is to organize relations between the debtor and its creditors and includes:

- Division of the creditors into groups with determining of how will be treated with claims in particular groups;

- Determination of the way of reorganization;

- Identification of measures to implement the reorganization plan, particularly in terms of dealing with the assets;

- Information, whether debtor's business or its parts are going to continue in the operation and under what conditions;

- Enumeration of the persons who will be involved in financing the reorganization plan or will take over some of the debtor's obligations or will ensure their performance, including the extent to which they are willing to do so;

- Information of how the reorganization plan will affect the employment in the debtor's business and the measures that will be implemented in this orientation;

- Information about the amount of obligations to creditors after the end of reorganization;

- Information of how will be ensure the performance of the claims regarding the incidental dispute and claims linked to suspense condition.

Reorganization under Insolvency Law may terminate by three different ways:

- Satisfaction of the reorganization plan;

- The transformation of reorganization into the bankruptcy;

- Cancellation of decision on the approval of the reorganization plan, in case of meeting a conditions testifying dishonest act.

The insolvency court takes note the fulfillment of the reorganization plan or its substantial parts by decision by which ends the reorganization.

\section{CASE OF SAZKA}

Within this part of the paper we will focus on specific case of Czech lottery company Sazka. The case of the Sazka lottery company is very interesting from numerous aspects and would deserve a book in itself. From the perspective of insolvency law, however, it is interesting to observe how it is possible to use an ostensibly use a method of liquidation in such a way that, at the end of insolvency proceedings, a company appears using the same brand name, to a large extent the same employees, the same know-how, but with completely different proprietors.

The actual collapse of the Sazka Company was caused by the fact that this company took the task of building a winter sports hall for the ice hockey world championships. As this building was being constructed, its budget grew to several times what had been originally planned and, after many 
peripateias, the consequences of Sazka's indebtedness became so serious that the company was unable to pay out winnings on time, and its financial situation became dramatically unsustainable. Halfway through February 2011 billionaire Radovan Vítek, who had bought bonds issued by Sazka from the Komerční Banka portfolio, filed an insolvency proposal through his companies; Sazka was in delay by several hundreds of millions for these receivables. At the end of March, the court declared the Sazka lottery company bankrupt. The management implemented reorganization as a solution to the bankruptcy - most probably because such an approach would mean that the management could retain its influence in the company. The management also tried to find an investor who could bring the resources necessary to remit the most acute outstanding debts - they were not successful, however.

At the end of May, the court announced a tender for Sazka's property. During this time, bets were still being made, lotteries organized by the company continued - albeit with considerable difficulties, because the vast majority of Sazka's terminals had been disconnected from the internet for a greater or lesser period of time. A complete cessation of betting nevertheless did not occur. However, terminals stopped functioning, as did recharging of prepaid mobile phone operator cards - Sazka had stopped transferring money to these operators, resulting in debts amounting to 600 million CZK.

In November, the insolvency administrator sold the Sazka business (i.e. the lottery section of the Sazka Company) to a duo of investors cooperating with one another who were also the biggest creditors. Sazka was thus acquired for 3.81 billion CZK by Petr Kellner's PPF group and Karel Komárek's KKCG. This price was reached in a public tender, amidst numerous protests against its rules; the Penta group even decided not to participate in the tender, but in a letter, they offered the insolvency administrator a much higher sum. Nevertheless, the tender continued to the end and the winners paid the purchase price. Penta, Česka Spořitelna and Sazka's other former shareholders, i.e. sport unions and organizations from the field of sport filed several lawsuits on the grounds that the tender had not proceeded in a standard way and that the best price had not been gained. Of course, PPF and KKCG continued with their standard financial offensive and also came to an agreement to purchase Česka Spořitelna's portion of the loan ( $\breve{C}$ s then dropped its lawsuit against Sazka's new proprietors); they also bought receivables from the mobile operators, which paved the way to renewing the terminals' activities - not only as betting stations, but also as places where pre-paid cards could be recharged.

Within a period of time shorter than one year - from March through November - the problem of Sazka's bankruptcy had been largely solved, albeit not in every detail. The sale of further property is still taking place, but the creditors have been paid since January 2012. On 12 January 2012, the insolvency court approved the insolvency administrator's proposal for a partial schedule, according to which the creditors' receivables have begun to be remitted.

It thus seems that the case of Sazka's bankruptcy will finally be solved within 12 months, despite very strong turbulence. This, however, was possible thanks to the fact that both strong investors had expended significant resources to implement their will in the insolvency proceedings. The insolvency administrator evidently wanted to have this case solved as soon as possible, and modified his behaviour and decision style towards fulfilling that purpose.

As regards the strategic and tactical side of things, the outcome of the Sazka company case shows that a claim against a company in bankruptcy can be an interesting item of merchandise under certain circumstances [11]. Even an apparently worthless debt can become interesting depending on the angle of approach during insolvency proceedings or it can be of significance during a vote at a creditors' meeting.

\section{CONCLUSION}

Current legal solution is effective for five years. The bankruptcy debtor's reorganization is the only way to address redevelopment decline which is now offered by the Czech legal system. Statistical surveys have shown how difficult is negotiating the reorganization plan to compile all groups of creditors, whose number within the group may be in the tens.

The period that elapses from the moment of insolvency proceedings until approved reorganization plan can be excessively long for the company. One reason for the introduction of a reorganization of bankrupt businesses is to prevent social and economic problems of the population in the region. "Reorganization" control alone is a long distance run solution that can last several years [11]. As arises from the statistics available, currently there was completed only one from the allowed reorganization, which is proof of its time-consuming.

\section{ACKNOWLEDGMENT}

This paper is one of the research outputs of projects P403/11/0002 registered at Czech Science Foundation (GAČR) and TD010093 registered at Technology Agency Czech Republic (TAČR).

\section{REFERENCES}

[1] D. G. Baird and R. K. Rasmussen, The End of Bankruptcy, University of Chicago, The Law School, John M. Olin Law \& Economics Working Paper, no. 173, 2002.

[2] L. A. Bebchuk, "A new approach to corporate reorganizations," 101 Harvard Law Review, no. 775, 1988.

[3] WKČR, Účetnictví Podnikatelů 2012, Prague: Wolters Kluwer, 2012.

[4] T. Richter, Insolvenční Právo 1st Edition, Prague: Wolters Kluwer, 2008, pp. 357.

[5] M. Žižlavský, "Soumrak restrukturalizace, úsvit reorganizace?" Bulletin advokacie, no. 6, 2010, pp. 28-30.

[6] F. Hanzlík, "Reorganizace jako øešení úpadku," Bankovnictví, no. 8, 2008 , pp. 31.

[7] B. A. Adler, Foundations of Bankruptcy Law, New York, Foundation Press, 2005.

[8] A. Bris, I. Welch, and N. Zhu, "The costs of bankruptcy, chapter 7 liquidation versus Chapter 11 reorganization," vol. 61, Journal of Finance, pp. 1253, 2006.

[9] E. Warren, "The untenable case for repeal of Chapter 11," 102 Yale Law Journal, 437, 1992.

[10] C. G. Bonaci, R. Mustata, and J. Strouhal, "Reporting business risks A necessity of sound corporate governance mechanisms," J. Politis (Ed.), in Proc. of the $8^{\text {th }}$ European Conference on Management Leadership and Governance, Paphos, vol. 8-9, 11, 2012, pp. 58-65. 
[11] L. Smrčka and J. Schönfeld, "The possibilities of reforming czech insolvency law," in Advances in Finance and Accounting, WSEAS Press, 2012.

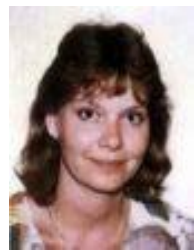

Monika Randáková is a senior lecturer of the Department of Financial and Managerial Accounting at Škoda Auto University, Mladá Boleslav, Czech Republic. She is a holder of auditing license and she tries to link her research and teaching practices with CPA profession. Her research interest covers accounting solution of bankruptcy issues.

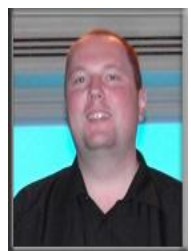

Jiř́ Strouhal is an associate professor of the Department of Financial and Managerial Accounting at Škoda Auto University, Mladá Boleslav, Czech Republic. He is also a President of the Chamber of Certified Accountants Czech Republic. His research interest covers international accounting harmonization and its impact on financial indicators, valuation and reporting for financial securities. He is a IEDRC fellow since 2011.

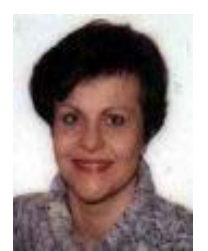

Jiřina Bokšová is an associate professor and a Heard of the Department of Financial and Managerial Accounting at Škoda Auto University, Mladá Boleslav, Czech Republic. Her research interest covers local accounting practices and reporting of insurance companies.

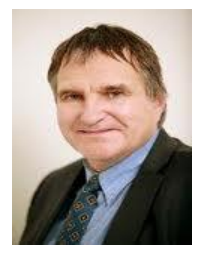

Luboš Smrčka is an associate professor of the Department of Business Economics at University of Economics Prague, Czech Republic. He also works as a bankruptcy trustee and is a certified tax advisor (member of a Chamber of Tax Advisors Czech Republic). His research interest covers micro- and macro- aspects of insolvency, private finance, taxation and financial reporting. .

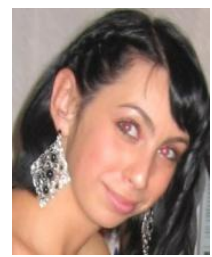

Raluca Simona Pindulina Bonaci finished her studies as an architect within the Technical University of Cluj. Currently she acts as an independent private consultant focused on business affairs. 